\title{
The Role of Capital Inflow through Saving-Investment Framework: The Case of Indonesia
}

\author{
Rufita Sri Hasanah ${ }^{1}$ \\ Ministry of National Development Planning/Bappenas - Indonesia
}

\begin{abstract}
As major developing countries have limited domestic saving to generate capital accumulation, capital inflow plays substantial role to provide external financing. Several landmark literatures provide an empirical evidence that capital inflow contributed to the acceleration of economic growth through technology transfer, enhanced innovation, and capital accumulation. This research examines the role of capital inflow for the case of Indonesia using saving-investment relationship with quarterly data from 2000 to 2018. This study is comprised of three parts to measure the pattern of capital inflow in overall period, pre-global financial crisis, and post-crisis. Building on previous literature, this study will contribute to fill the gaps in existing literatures by employing error correction model (ECM) based on saving-investment framework of Feldstein-Horioka. This study found that over the whole sample period and post-crisis, both domestic saving and national saving in short-run, established low significant coefficient which signify high capital mobility, while in the long-run, domestic investment and saving have one-to-one relationship, which does not necessarily imply low capital mobility. The result on the precrisis period suggested that domestic saving and domestic investment is not statistically correlated for both short-run and long-run as there is not enough evidence to reject null hypothesis. This study confirms the growth theory model that suggests saving will be equal to investment in the steady state condition and the imbalance of saving and investment will be only transitory.
\end{abstract}

Keywords: capital inflow, saving investment, economic growth

\footnotetext{
${ }^{1}$ Rufita Sri Hasanah is a Planning staff at the Directorate of Macro Planning and Statistical Analysis, Ministry of National Development Planning / Bappenas RI. E-mail: rufita.hasanah@bappenas.go.id
} 


\title{
The Role of Capital Inflow through Saving-Investment Framework: The Case of Indonesia
}

\author{
Rufita Sri Hasanah
}

\section{Introduction}

Most of developing countries encounter financial constraint to meet their required investment. Bosworth and Collins (1999) argue that several developing countries possess low output due to limited capital accumulation. This challenge caused by inadequate domestic saving to finance the required investment which in turn could potentially hamper economic growth in the future. Foreign capital inflow is believed to contribute to achieve higher amount of capital accumulation and amplify private saving which in turn provides the host countries to invest and consume more than they could have done otherwise (Caselli \& Feyrer, 2007). Grilli and Milesi-Ferretti (1995) highlight the potential benefit of foreign capital inflow to promote more disciplined macroeconomic policies by implementing rewards and punishments system in implementation of policies. Furthermore, Ahmed and Zlate (2014) examined that international capital inflow could improve efficiency of capital allocation and productivity.

The rapid capital inflow in Indonesia during pre-crisis period, 1980 to $1996 \mathrm{had}$ played significant role to promote economic growth. Indonesia achieved one of the highest economic growth among Asian countries. Based on IMF data, Indonesia grew at an average of 7.2 percent and inflation remained stable at below 10 percent. This remarkable growth thus in turn to help opening job opportunities. Data from world bank recorded that unemployment rate could be managed below 5 percent. Foreign reserves also rose dramatically from USD2.5 billion to USD17.8 billion (Goeltom, 2008). Since government focused on attracting foreign capital inflow, domestic interest rate was maintained at the competitive level against foreign interest rate.

The effect of this capital inflow can also be observed by analysing the expansion of money supply. During the pre-crisis period, narrow money supply (M1) and broad money supply (M2) grew up to 26.9 percent and 20.0 percent respectively (Bank Indonesia, 2018). Increased aggregate demand, which exceeded the capacity in productive sectors led to overheating in the Indonesia's economy along with high economic growth and inflation. Although government implemented deregulation of financial system, the reforms were not followed with the sound regulatory and supervisory framework. Goeltom (2008) highlighted that inefficient financial system due to insufficient regulatory and supervisory framework, bad governance, lack of prudential principle, and highly regulated credit allocation brought financial system to be uncertain and fragile.

Furthermore, an asset price bubble could not be avoided due to expansion in the real estate which was mostly funded by credit and offshore borrowing. The debt stock, dominated by private sector borrowing rose significantly from USD64 billion in 1990 to USD110.2 billion in 1996 (Bank Indonesia, 2018). This sharp increase in offshore borrowings was caused by high domestic interest rate, therefore domestic investor sought alternative funding which had lower interest rates. However, offshore borrowings became one of the riskiest investments since it highly depended on volatility of currency and fraught with maturity mismatches. In addition, many private sector investors were not aware the importance of hedging their offshore borrowings due to an implicit guarantee of managed floating exchange rate system. These conditions led the Indonesia's economy become more vulnerable to domestic and international shocks.

Thus, the weak fundamentals of the economy, as highlighted earlier, meant that the country was exposed to the economic shocks, that ultimately arrived in the form of 
currency crisis in 1997. The rupiah lost its value, making foreign debt and debt servicing more expensive and led several companies to bankruptcy. The currency crisis caused deficit in the balance of payment for the first time since 1989 due to massive private capital outflow. Although there was a significant increase in government capital inflow from domestic creditors and international financial institutions under IMF coordination, the amount was inadequate to cover the deficit in capital account due to massive private capital flight. As a result, the capital account decreased sharply from USD 11 billion in 1996 to USD2.5 billion in 1997 and widened further into deficit USD 4.6 billion in 1999. Indonesia's central bank implemented contractionary monetary policy with sharp increase in domestic interest rate to prevent further capital outflow and exchange rate collapse.

This financial liberalization turmoil has escalated the debate about the potential benefits and risks of capital inflow to developing countries such as Indonesia. DemirgucKunt and Detragiache (2001) believed that financial liberalization is one of the factors to create crisis. They argued that financial liberalization followed by massive credit growth had eroded the quality of lending. Market discipline was deteriorated by government guarantees while weak financial supervision and regulation could not prevent moral hazard (Dooley, 2000). Moreover, Bosworth and Collin (1999) discussed the potential effect of capital inflow in transforming the resource that might have no effect on investment. They argued that capital inflow might be mostly used for consumption and offset by capital outflows and reserve accumulation.

This study examines the role of capital inflow through saving-investment framework to in the case of Indonesian economy. We employ a time series analysis using saving and investment relationship which developed by Feldstein and Horioka (1980) framework. This framework suggested that in the world of perfect capital mobility across the border, the role of capital inflow could be captured by assessing the degree of correlation between saving and investment since the capital would flow from the countries that have high degree of saving to other countries that need money to fund the investment.

\section{Literature Review}

Evaluation on the impact of capital flow through saving and investment relationship on economic growth is crucial in order to formulate an optimal saving policy. Feldstein and Horioka (1980) examined that if the capital moves freely between countries, the relationship between domestic saving and domestic investment would be low. Since investment in the home country would be funded by the global pool of capital while saving in each country would respond to the global opportunities of investment, the difference in investment rate between countries should respond firmly to difference in saving rate if additional increase on saving were invested in the home country. Using cross section data on OECD countries, Feldstein and Horioka (1980) found low level of international capital movement as the unity test were not significant and significantly different from zero for estimated coefficient. They investigated the probability that the movement of domestic saving and domestic investment would depend on the level of openness of the economy and the size of the economy. However, the finding suggested that the variation of international capital movement and the size of economy is not significant while the correlation between domestic saving and domestic investment may differ across countries.

Sensitivity analysis was conducted to check the probability of equation bias. Feldstein and Horioka (1980) employed an instrument variable for saving which consist of percentage of change in income private income, ratio of dependents and those receiving pension benefits in the total population, the ratio of benefit-earning of social security net and the total labour participation rate in the population. The finding then suggest that domestic saving and domestic investment are correlated. Furthermore, Sachs (1983) continued the investigation by employing robustness check on saving and investment relationship through the difference between these variables. The author interpreted that 
the current account in the balance of payment is a proxy to measure the difference between domestic saving and domestic investment as an indicator of international capital flow. Employing LDC and OECD countries data, Sachs (1983) examined the correlation between current account and national saving and domestic investment. The findings suggested that the changes in investment is highly influenced by the changes in current account rather than saving. Although the study did not reveal the clear relationship between saving, investment, and current account, the result of the estimation provided evidence that the relationship between investment and current account is significant.

However, many literatures documented that high degree of correlation between domestic saving and investment do not necessarily signify low international capital movement. Razin and Sadka (1995) concluded that population, technology, and productivity in each country which considered as endogenous shock might cause domestic saving and domestic investment increase simultaneously, thus these variables would move one to one. Moreover, Frankel and Dominguez (1994) analysed the close correlation between interest rate and gross asset movement among industrialized countries indicates high degree of financial integration. Gordon and Bovenberg (1994) emphasized that capital market imperfection due to asymmetric information across countries would cause domestic saving and domestic investment has one to one correlation.

Critique on Feldstein-Horioka study also lies on the utilization of large industrialized countries sample that would potentially overestimate the correlation between saving and investment. Tesar (1991) argued that large size economies would likely have a relatively large share of global saving and investment as these economies tend to have power to influence world's interest rate. For instance, large industrialized country such as United States, saving and investment would potentially move together in the middle of integrated capital market. A decrease in domestic saving will induce both domestic and world interest rate to increase and pull out investment internationally. It would be erroneous to conclude that strong correlation between saving and investment is indictive of a close international capital market.

Moreover, Harberger (1980) showed that small economies would likely to have large volume of capital flows than large size industrialized countries. Another study conducted by Murphy (1984) showed that the inclusion of small economies has reduced the correlation between saving and investment. Similar result suggested that the correlation between saving and investment in developing economies is lower than in large industrialized economies (Dooley et al., 1987). Weaker correlation between saving and investment in developing countries occur due to small amount of international capital that likely finance domestic investment (Gertler \& Rogoff, 1989). The authors explained that the demand of International fund to finance domestic investment in developing countries are higher than in developed countries. In advanced economies, domestic savings are sufficient to finance domestic investment, therefore the demand of external financing are lower.

On the other hand, a favourable support to Feldstein and Horioka hypothesis was examined by Bayoumi and Rose (1993). The authors employed regression on data in UK regions as these areas has highly capital mobility environment. The result showed that there is no evidence that the changes in UK regional saving is significant to the changes in UK regional investment. Another study conducted by Bayoumi and Sterne (1993) and Obstfeld (1993) using other countries data such as Canada and Japan which also have high degree of capital mobility found similar result. Based on the observation of GNP/GDP ratio across several European countries and UK regions, Bayoumi et al. (1999) was concluded that the capital flows are more freely to move within national economy than globally. Overall, these findings confirm the Feldstein-Horioka hypothesis that under a perfect capital mobility, the correlation between saving and investment will be zero. 
In general, the arguments regarding saving-investment relationship of FeldsteinHorioka framework lies at the theoretical level. Although a number of literatures discarded the interpretation of high correlation between saving investment relationship implies low international capital integration, a numerous distinguished literature provides favourable support to Feldstein-Horioka hypothesis. While the interpretation of the regression of saving-investment correlation is still unclear and ambiguous, the analysis of savinginvestment may be beneficial and valuable for the issue of international capital mobility, particularly when equipped by other empirical evidence.

\section{Methodology}

This study utilizes quarterly data from Indonesia's Central Bureau of Statistic (BPS), International Financial Statistic (IFS) of International Monetary Fund (IMF), and Central Bank of Indonesia (Bank Indonesia) for the period 2000 to 2018. The data used in this study comprise of gross fixed capital formation and the changes of inventory which available in Indonesia national account data as the proxy of domestic investment. Moreover, national saving data was extracted from domestic investment plus current account balance which was taken from balance of payment data provided by central bank of Indonesia. While domestic saving data was gathered from GDP minus consumption expenditure and government purchase. The estimation of saving and investment relationship is constructed based on Feldstein and Horioka (1980) framework.

Saving and investment relationship is derived from the identity equation of Gross Domestic Product (GDP) where it consists of the sum of goods and services produced domestically. In expenditure method, GDP will be equal to the sum total of spending on all finished goods and services, including the sum of consumption, government purchases, investment, and net export (equation 1). Therefore, the value of investment can be obtained by subtraction of the total value of final goods and services produced (GDP) to consumption expenditure, government purchase, and net export (equation 2). While GDP minus consumption and government purchase equals to domestic saving, national saving is taking into account the amount of net factor income from abroad (NFIA).

$$
\begin{gathered}
G D P=C+I+G+N X \\
G D P-C-G-N X=I \\
S_{D}-N X=I_{D}
\end{gathered}
$$

NFIA is the difference between the factor income earned abroad from resident in home country and the factor income receive by non-resident in home country. This variable is substantial to measure foreign capital flow as this variable reflects the amount of capital flow from abroad to domestic economy or vice versa. While NFIA and domestic saving reflect national saving, NFIA plus net export indicate current account or Net Foreign Investment (NFI). Thus, domestic saving and NFI will be equal to national investment.

$$
\begin{aligned}
N F I A+S_{D}-I_{D}= & N X+N F I A=C A=N F I \\
& N F I A+S_{D}=I_{D}+N F I \\
& S_{N}=I_{D}+N F I=I_{N}
\end{aligned}
$$

The equations above suggest that saving is driven by the amount of investment. In the economy where it does not have international trade, the amount of investment is financed by domestic saving. Therefore, the equations above confirmed the empiric evidence that foreign capital plays important role for the country that has limitation in drawing capital accumulation. Bosworth and Collins (1999) contend that instead of raising the level of investment, capital inflow is more likely to contribute to increase in the consumption, thus reduce saving. The Feldstein-Horioka framework confirmed this 
condition that in the absence of the role of capital inflow, the saving and investment would have one-to-one correlation.

$$
\begin{gathered}
\frac{I_{t}}{Y_{t}}=\alpha+\beta \frac{S_{t}}{Y_{t}} \\
\frac{S_{t}}{Y_{t}}-\frac{I_{t}}{Y_{t}}=\alpha+(1-\beta) \frac{S_{t}}{Y_{t}} \\
\frac{N F I_{t}}{Y_{t}}=\alpha+(1-\beta) \frac{S_{t}}{Y_{t}}
\end{gathered}
$$

Jansen and Schulze (1996) argue that the regression to estimate saving-investment relationship cannot be acquired from theoretical framework because it is not the part of behavior relation in model (structural relationship) or solution of the system (reduced form). Major literatures provide evidence on relationship between the level of saving and investment, the first difference analysis, and level of saving and investment over various time period. However, modern macroeconomic theory suggests that the model specifications would likely unsuitable with the theoretical framework. This unfitness would draw consequences which could lead to unfounded conclusion. Genberg and Swoboda (1992) explain the difficulties to draw conclusion from estimating saving-investment relationship equation which come from various specification because of limited theoretical framework to interpret. For example, it is hard to distinguish the contribution of studies using period-average data in cross-section and time series data in determining the capital mobility without accompanied by reliable theoretical framework.

Both cross-sectional data analysis and time series regression analysis have become the go to approaches to estimate the correlation and causality between saving and investment. The cross-sectional approach is employed to investigate the correlation between saving and investment over a particular period of time, spanning over a year or multi-year data. Jansen and Schulze (1996) discussed the possibilities of mis-specified regression equation due to neglecting the intemporal general equilibrium that caused static correlation between saving and investment. Moreover, period-average data would generate incompatible estimation of saving-investment relationship to draw conclusion on the degree of foreign capital movement. Sinn (1992) highlights the matching trend between saving and investment averaged over a long period, owing to the intertemporal budget constraint of the households. However, averaging over long periods lead an upward bias in the estimation of saving and investment relationship.

Research based on the country-specific time series analysis of saving and investment relationship chiefly utilized four different type of model specifications. The estimation equation estimated by Frankel (1991), as follow:

$$
i_{t}=\theta_{0}+\theta_{1} s_{t}+\varepsilon_{t}
$$

The saving-investment specified in equation (10) is unable to cover the dynamic adjustment process. In order to capture dynamic relationship between saving and investment, Feldstein and Bacchetta (1991) and Bayoumi (1990) employed first difference analysis to estimate the saving-investment correlation,

$$
\Delta i_{t}=\alpha+\beta \Delta s_{t}+\mu_{t}
$$

One limitation of employing the equation 11 is that, despite, it measures short-run relationship, it does not provide any solution for the static equilibrium as it does not imply anything about the steady state saving and investment level. Bayoumi (1990), came up with the first difference approach in his study to make these series stationary. Despite that, Engle and Granger (1987) argue that the eq. (11) can only justly specify the long-run correlation between saving and investment if there is no long-run cointegration problem in the series. Thus, as the theory signifies that eq (11) is over differenced, it would likely to be mis-specified. Feldstein and Bacchetta (1991) contended that lagged adjustment could be 
an effective technique to estimate the saving and investment correlation as the investment pattern exhibit the tendency to react to the gap between saving and investment in the previous periods:

$$
\Delta i_{t}=\alpha+\beta\left(s_{t-1}+i_{t-1}\right)+\mu_{t}
$$

Jansen and Schulze (1996) argue that the model specification based on lagged adjustment, however, restricts the short-run correlation between saving and investment to zero and thus imposes limitation structural dynamism. It is, thus, contended that justifying this restriction could lead to debatable results, so eq. (12) would likely lead to misspecification model. In summary, specification (10)-(12) may lead to unjustified interferences. The equations (10) and (11), could be effective following the theoretical framework where the saving and investment relationship is not viewed as a solution for intertemporal budget constraint problem. Lately, there is a growing trend of employing the cointegration techniques to examine the saving-investment relationship in time series regressions (Miller, 1988; Leachman, 1991; Vikaren, 1994; and De Haan \& Siermann, 1994). However, many strand studies employed Engle-Granger two-step procedure, except study conducted by Vikmen (1994). In the first step the static regression equation (10) is ran, there after the residuals are test for stationarity to detect the cointegration, if any. Leachman (1991) could not find any evidence of cointegration between saving and investment in any of the twenty-three members of OECD and opined that the difference equation (11) could be used in estimating the saving and investment relationship more efficiently. De Haan and Siermann (1994), however, have casted doubt over these results because of low power of the cointegration test results, as the data used for the analysis was short-run time series data and only spanned over twenty-five years. On the other hand, when the analysis was extended to time series data over ten countries of OECD, cointegration problem for many countries was detected.

Based on the shortcoming of the model specification discussed above, this study follows theoretical framework of Blanchard and Fischer (1989) which assume open economy analysis in the modern macroeconomic framework. The analysis is based on both generational gaps and infinitely lived representative models where agents maximize their utility function subject to their intertemporal budget constraint as capital is assumed to be completely mobile, they can recourse to international capital market to smoothen their consumption patterns. This study takes into account the role of general equilibrium models with focus on steady states in which current account (valued as share per GDP) is constant. As a result, saving and investment would have one-to-one relationship in the steady state. For instance, the role of sustained current account deficit and surplus would be excluded in saving and investment equation. The one-to-one relationship between saving and investment does not necessarily imply limited capital mobility. In the short-run when the shocks to the system cause the economy and saving and investment thereof to move away from its steady-state position, the relationship of saving and investment would yield to non-zero, despite perfect capital mobility (Buiter, 1981; Persson \& Svensson, 1985; Obstfeld, 19861; Matsuyama, 1987; Finn, 1990; Leachman, 1991; and Koch, 1992).

The type and the magnitude of the shock as well as the structure of the economy would determine the sign and the size of saving-investment relationship. These exogenous variables also affect the level of saving and investment in new steady state. Jansen and Schulze (1996) examined that these variables play significant role to construct econometric specification. Firstly, the steady state value of saving and investment might become nonstationary variables as their exogenous variables are non-stationary. Secondly, there might exist co-integration between saving and investment as these variables move independently in the steady state, despite its value. Engle and Granger (1987) demonstrated that these characteristics which exhibit stationarity can be represented by error correction model. 
Based on the literature reviewed, Vikaren (1994) is the first to apply an augmented approach with an error correction model as incompletely specified regression. Employing Sachs (1981) framework, he contends that saving-investment regression analysis should be based on the distinction between the short-run relationship, which signifies the nature of capital mobility, and the long-run relationship, which is indicative of the intertemporal budget constraint. Nonetheless, the model specification follows the theoretical framework based on two period economy, where only one saving and investment determination are built. In the following period, the terminal condition of economy sets in, making the investment zero and the income and wealth are completely absorbed. The framework used by Vickeran (1994), has obvious shortcomings as it prohibits any dynamic savinginvestment analysis. It is very substantial to analyse an economy which has infinite periods to meaningfully diagnose the short and long run relationship between saving and investment. Thus, for its obvious limitations, Vikeran's analysis on short and long run relationship between saving and investment are based on erroneous reasoning, even though the logic behind these stems from static equilibrium models. Moreover, the two steps of Engle-Granger procedures are utilized to complete the error correction model specification. The test simultaneously estimated the short and long run dynamics. By testing $\gamma=0$, it would result to conduct cointegration test. Kremers et al. (1992) argue the advantage of cointegration test lies on the high power it produces than the orthodox tests. The specification of error correction model as follow:

$$
\Delta i_{t}=\alpha+\beta \Delta s_{t}+\gamma\left(s_{t-1}-i_{t}\right)+\delta s_{t-1}+\mu_{t}
$$

where $i_{t}$ and $s_{t}$ represent the ratio of saving and investment to the country's output, and $\mu_{t}$ is a well-behaved disturbance. The short-run correlation can be analysed by estimating the changes of saving and investment, represented by the parameter $\beta$. While the long-run relationship between saving and investment can be obtained as steady-state solution, as follow:

$$
\alpha+\gamma(\bar{s}-\bar{i})+\delta \bar{s}=0
$$

In the long-run, current account which represent saving-investment gap is a result of $\delta=0$, while if $\alpha=\delta=0$, the saving-investment gap would exhibit zero. This both conditions would generate saving and investment move dependently in long run. Strand literatures mentioned that a perfect relation between saving and investment in the long run implies perfect capital movement. Jansen and Schulze (1996) recommended to conduct parameter restrictions test to assert whether steady-state relations are consistent with the data. The methodology employed in the study follows the theoretical framework which endeavors to offer all the explanations related to non-zero and zero relationship between saving and investment, considering capital flow, real interest rate differentials and government stabilization measures. All these variables consolidate the prophecy that the current account remains constant in the long run and the saving and investment are temporary events.

This paper will estimate the equation (13) for two sample periods, 2000 to 2007 and 2008 to 2018. The first sample period was a recovery period after Asian financial crisis. Moreover, in this period, government of Indonesia implemented major economic reform and address root causes, such as changes monetary framework, adopt prudent budget policy, and financial reform. In regard of monetary framework, Indonesian central bank previously adopted crawling band exchange rate before Asian financial crisis and shifting to nominal anchor. For a prudent budget policy, Indonesia now implement fiscal discipline which regulate the maximum level of fiscal deficit up to 3 percent of GDP and maximum debt to GDP is 60 percent. In financial reform, government restructured banking system and strengthen law and supervision. The second sample period is a period after global financial crisis. The aim on dividing this sample period is to gain understanding whether 
there has been changing pattern on saving, investment, and foreign capital inflow before and after global financial crisis. As Feldstein-Horioka framework posits in their study that high correlation of saving and investment implies low foreign capital movement.

\section{Result}

This study employs regression in level, differences, and error correction model (ECM) on quarterly data for Indonesia over the period $2000-2007$ and 2008-2018. Domestic investment is specified by private and government net investment, comprising of changes in stock. While saving consists of domestic saving and national saving. Furthermore, both saving and investment are stated as ratio to GDP. Based on FelsteinHorioka framework, there would be one to one relationship between saving and investment if the movement of capital is limited. Therefore, in this study, parametric restriction test was performed to check whether domestic saving and domestic investment move together, thus the null hypothesis based on FH framework stated as $\beta=1$ and $\gamma=1$. Moreover, this study employs the robustness check using current account and national saving which also reflects net foreign investment in eq (9). Since this study believes that in the case of Indonesia, saving and investment relationship would yield zero estimation due to higher degree of capital mobility, the robustness check is expected to show that saving would be correlated with current account to represent net foreign investment. The null hypothesis can be defined as $\beta=0$ and $\gamma=0$, thus we expect both short-run and long-run would reject the null hypothesis. This implies that foreign capital inflow would play role in closing the gap of lacking saving.

\section{Overall Period (Pre-Crisis and Post Crisis)}

This section will discuss the estimation using OLS regression in level. Difference, and ECM for the period $2000-2018$.

Table 1. Domestic Investment and Domestic Saving

\begin{tabular}{|c|c|c|c|c|c|c|c|c|}
\hline \multicolumn{2}{|r|}{$\alpha$} & \multirow{2}{*}{\begin{tabular}{|c|c|c}
\multicolumn{1}{c}{$\boldsymbol{\beta}$} \\
$0.4860^{* * *}$ \\
$(0.0610)$
\end{tabular}} & \multirow[t]{2}{*}{$\boldsymbol{\theta}$} & \multirow[t]{2}{*}{$\gamma$} & \multirow{2}{*}{$\begin{array}{c}\boldsymbol{R}^{\mathbf{2}} \\
0.4574\end{array}$} & \multirow{2}{*}{$\begin{array}{l}\text { DW } \\
2.4795\end{array}$} & \multirow{2}{*}{$\begin{array}{c}\boldsymbol{\beta}=\mathbf{1} \\
0.0000\end{array}$} & \multirow{2}{*}{$\gamma=1$} \\
\hline$\Delta i$ & $\begin{array}{l}0.2397 \\
(0.2397)\end{array}$ & & & & & & & \\
\hline$i$ & $\begin{array}{l}- \\
11.3382^{* * * *} \\
(2.4017)\end{array}$ & $\begin{array}{l}1.3000^{* * *} \\
(0.0786)\end{array}$ & & & 0.7870 & 1.2838 & 0.0003 & \\
\hline$\Delta i$ & $\begin{array}{l}-2.1087 \\
(2.0401)\end{array}$ & $\begin{array}{l}0.2783^{*} * \\
(0.1000)\end{array}$ & $\begin{array}{l}- \\
0.2456^{* * * *} \\
(0.0817)\end{array}$ & $\begin{array}{l}1.2378^{*} * * \\
(0.2186)\end{array}$ & 0.5322 & 2.2665 & 0.0000 & 0.2804 \\
\hline \multicolumn{9}{|c|}{$\begin{array}{l}\text { *, **, *** represent } 10,5 \text {, and } 1 \text { percent level of significance, respectively. Unit root test by Augmented Dickey- } \\
\text { Fuller (ADF) test suggests that both domestic saving and investment series are integrated of order one or I (1). }\end{array}$} \\
\hline \multicolumn{9}{|c|}{$\begin{array}{l}\text { Table } 2 \text { shows the saving-investment relationship through domestic saving. The } \\
\text { estimation for the short-run coefficient }(\theta) \text { is significant at any level of confidence. While } \\
\text { the coefficient in the long-run }(\gamma) \text { also establish significant relationship. However, the unity } \\
\text { test indicated only short-run has statistically different from unity. While the unity test for } \\
\text { the long-run showed that it is statistically not different from unity. It indicates that in the } \\
\text { short-run the movement of foreign capital is quite high, while in the long-run the result } \\
\text { shows one-to-one correlation between saving and investment. }\end{array}$} \\
\hline
\end{tabular}

Table 2. Domestic Investment and National Saving 


\begin{tabular}{|c|c|c|c|c|c|c|c|c|}
\hline \multicolumn{2}{|r|}{$\alpha$} & $\beta$ & $\boldsymbol{\theta}$ & $\gamma$ & $R^{2}$ & DW & $\beta=1$ & $\gamma=1$ \\
\hline$\Delta i$ & $\begin{array}{l}0.1539 \\
(0.1709)\end{array}$ & $\begin{array}{l}0.7750^{* * * *} \\
(0.0547)\end{array}$ & & & 0.7294 & 2.6916 & 0.0001 & \\
\hline$i$ & $\begin{array}{l}-9.2282^{* * * * *} \\
(1.5583)\end{array}$ & $\begin{array}{l}1.3062^{* * * *} \\
(0.0540)\end{array}$ & & & 0.8878 & 0.8095 & 0.0000 & \\
\hline$\Delta i$ & $\begin{array}{l}-1.6604 \\
(1.2407)\end{array}$ & $\begin{array}{l}0.5613^{* * * *} \\
(0.0949)\end{array}$ & $\begin{array}{l}-0.2031^{* * * *} \\
(0.0721)\end{array}$ & $\begin{array}{l}1.2927^{*} * * * \\
(0.1654)\end{array}$ & 0.7604 & 2.4514 & 0.0000 & 0.0812 \\
\hline
\end{tabular}

*, **, *** represent 10,5, and 1 percent level of significance, respectively. Unit root test by Augmented DickeyFuller (ADF) test suggests that both national saving and investment series are integrated of order one or I (1).

However, the regression has similar result when we employed saving-investment relationship with regard of national saving at 5 percent level of significant. Both short-run and long-run coefficient are significant at all level of significant. Furthermore, the unity test indicated that both short-run is statistically different from unity while long-run unity test is statistically insignificant at 5 percent level of significant, however it is statistically significant at 1 percent level of confidence. These findings also consistent with previous study conducted by Jensen and Schulze (1996). They found the low significant coefficient in the short-run as it reflects to an "inverted" Feldstein-Horioka puzzle. This findings regarding the unity test in the short-run and long-run coefficient match with our descriptive data in the presence of higher degree of economic openness.

Table 3. Net Foreign Investment (ca) and National Saving

\begin{tabular}{|c|c|c|c|c|c|c|c|c|}
\hline & $\alpha$ & $\beta$ & $\boldsymbol{\theta}$ & $\gamma$ & $R^{2}$ & DW & $\boldsymbol{\beta}=\mathbf{0}$ & $\gamma=\mathbf{0}$ \\
\hline$\Delta c a$ & $\begin{array}{l}-0.1181 \\
(0.1872)\end{array}$ & $\begin{array}{c}0.0901 \\
(0.0599)\end{array}$ & & & 0.0300 & 2.7974 & 0.1373 & \\
\hline$c a$ & $\begin{array}{l}9.6540^{* * *} \\
(1.5259)\end{array}$ & $\begin{array}{l}- \\
0.3211^{* * * *} \\
(0.0529)\end{array}$ & & & 0.3328 & 0.7270 & 0.0000 & \\
\hline$\Delta c a$ & $\begin{array}{l}1.9300 \\
(1.3762)\end{array}$ & $\begin{array}{l}0.1114^{*} \\
(0.0603)\end{array}$ & $\begin{array}{l}- \\
0.2215^{* * *} \\
(0.0797)\end{array}$ & $\begin{array}{l}- \\
0.3037^{*} \\
(0.1661)\end{array}$ & 0.1269 & 2.5014 & 0.0687 & 0.0717 \\
\hline \multicolumn{9}{|c|}{$\begin{array}{l}\text { *, **, *** represent } 10,5 \text {, and } 1 \text { percent level of significance, respectively. Unit root test by Augmented Dickey- } \\
\text { Fuller (ADF) test suggests that both current account and national saving series are integrated of order one or I } \\
\text { (1). }\end{array}$} \\
\hline \multicolumn{9}{|c|}{$\begin{array}{l}\text { The result presented by table } 3 \text { indicates that both short-run and long-run } \\
\text { cient are statistically significant. Moreover, the parametric restriction test indicates } \\
\text { oth short-run and long-run coefficient are statistically not different from zero at } 5 \\
\text { at confidence level, but significantly different from zero at } 1 \text { percent level of } \\
\text { icance. Therefore, it may be concluded that during the period of } 2000 \text { to } 2018 \text {, capital } \\
\text { would likely move together with national saving. }\end{array}$} \\
\hline
\end{tabular}




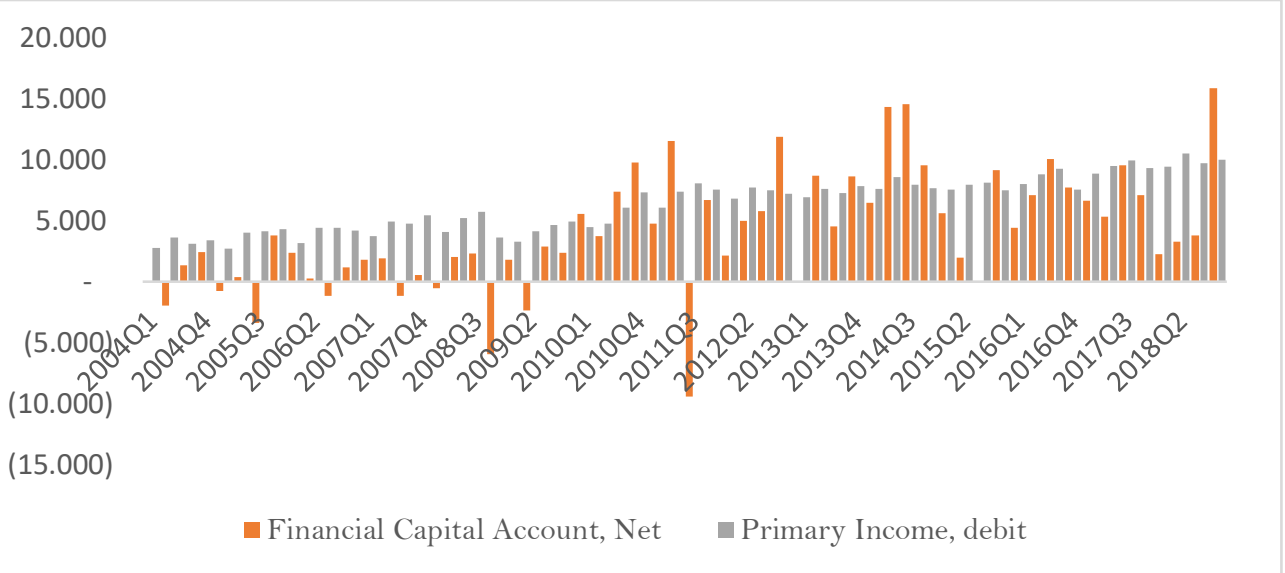

Figure 1. Income Payment and Financial Account (Million USD) Source: Bank Indonesia

The result for the correlation between domestic saving, national saving, and domestic investment revealed that saving and investment have one to one relationship in the long-run over the whole period. Based on the graph above, it may indicate that capital inflow was offset by the net factor income abroad as the figure shows the amount of capital inflow and primary income payment relatively same. Alternatively, it may indictive of the fact that domestic saving levels were relatively high in the wake of high burden to pay for the factor income abroad and the resultant foreign capital influx were used to fund required investment (Hadiwibowo, 2010). In many instances the Income payments were more than the financial account. There was greater burden to service foreign investment, hence, the squeeze was on. In other words, there was net outflow of resources from Indonesia. Net resource outflows coincided capital inflows posing the challenge to the country on two fronts. The result in this study provides evidence in support of Bosworth and Collins (1999) contention that capital inflows are not always equal to the transfer of resource. In the case of Indonesia, capital inflows have been offset by net factor income payment. In general, the theoretical framework sets the basis for expectation that capital inflows would contribute to increase net resource inflows, thus generate higher investment.

In the following session, we examine into the possibility of different time period patterns. Figure 1 shows the time series data for domestic saving rate, national saving rate, and domestic investment rate. It is shown that from 2000q 1 to 2018q4, the series move together, except during Global Financial Crisis. Saving rate decreased dramatically while domestic saving and investment increased. Stable domestic saving and investment is due to strong Indonesia's fundamental in that period compared to the Asian Financial crisis. Financial institution reform, strong international reserves, and stable macroeconomic condition were able to strengthen the economy during crisis. However, due to global economy slowdown and limited liquidity, net export was also affected. Since Indonesian export experience downward trend during global financial crisis, net foreign investment also decreased. Since national saving formed by net export and net factor income from abroad (NFIA), the value of national saving decreased as it shows in the graph. 


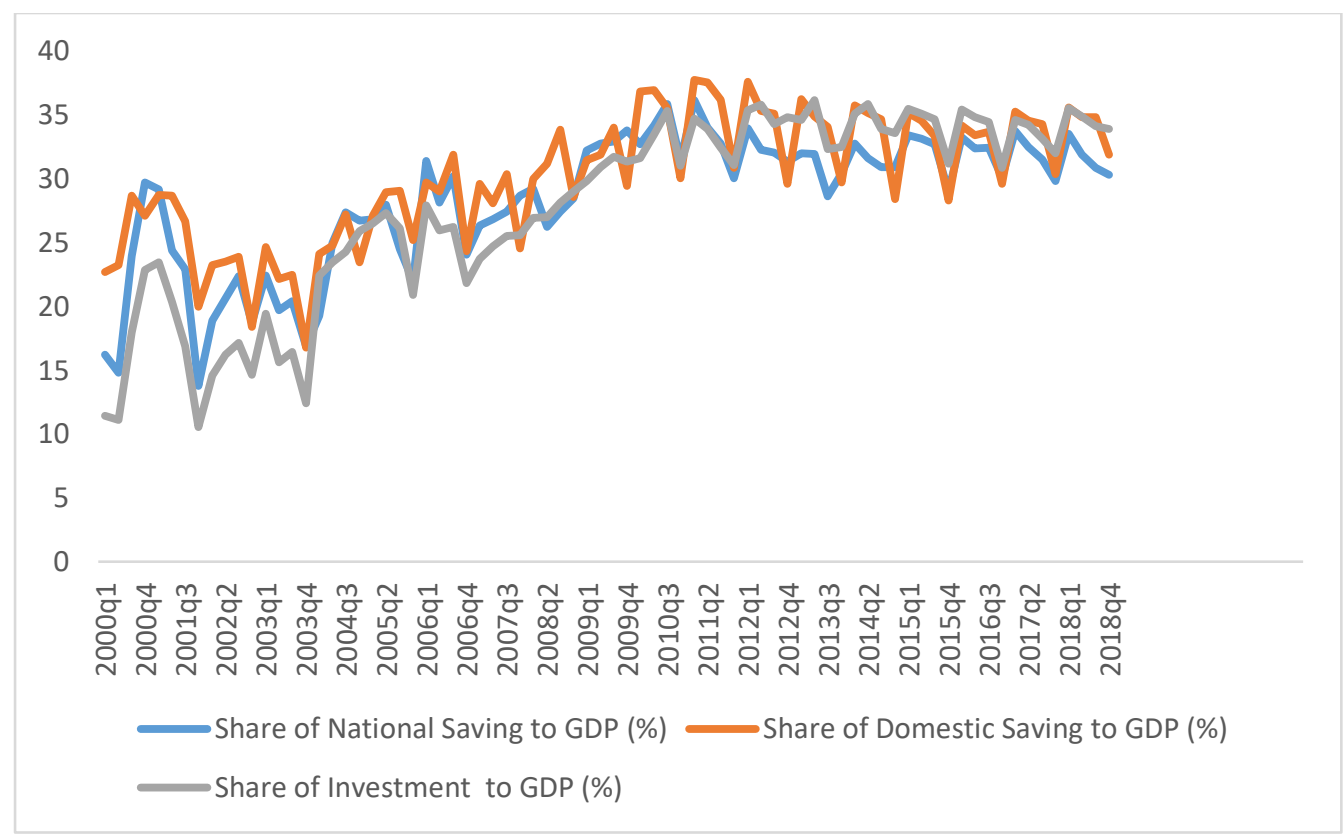

Figure 2. Domestic Saving Rate, National Saving Rate, and Domestic Investment Rate Source: Indonesia Central Bureau Statistic

\section{Pre-Global Financial Crisis}

This section will discuss the estimation using OLS regression in level. Difference, and ECM for the period $2000-2007$ (pre-crisis).

Table 4. Domestic Investment and Domestic Saving during Pre-crisis Period

\begin{tabular}{|c|c|c|c|c|c|c|c|c|}
\hline & $\alpha$ & $\beta$ & $\boldsymbol{\theta}$ & $\gamma$ & $R^{2}$ & DW & $\beta=1$ & $\gamma=1$ \\
\hline$\Delta i$ & $\begin{array}{l}0.1868 \\
(0.1412)\end{array}$ & $\begin{array}{l}-0.1270^{* * * *} \\
(0.0364)\end{array}$ & & & 0.2953 & 1.6741 & 0.0000 & \\
\hline$i$ & $\begin{array}{l}-8.1534^{*} \\
(4.6130)\end{array}$ & $\begin{array}{l}1.1247^{* * * *} \\
\text { (O.1787) }\end{array}$ & & & 0.5690 & 0.6523 & 0.4907 & \\
\hline$\Delta i$ & $\begin{array}{l}1.2333 \\
(4.1280)\end{array}$ & $\begin{array}{l}0.5835^{* * * *} \\
(0.1872)\end{array}$ & $\begin{array}{l}-0.2243 \\
(0.1353)\end{array}$ & $\begin{array}{c}0.6555 \\
(0.7582)\end{array}$ & 0.6461 & 1.8935 & 0.0346 & 0.6533 \\
\hline
\end{tabular}

*, **, *** represent 10,5 , and 1 percent level of significance, respectively. Unit root test by Augmented DickeyFuller (ADF) test suggests that both domestic saving and investment series are integrated of order one or I (1).

Table 4 shows the saving-investment relationship through domestic saving. The regression for both short-run coefficient $(\theta)$ and long-run coefficient $(\gamma)$ are not statistically significant at all level of significance.

Table 5. Domestic Investment and National Saving during Pre-crisis Period 


\begin{tabular}{|c|c|c|c|c|c|c|c|c|}
\hline & $\alpha$ & $\beta$ & $\boldsymbol{\theta}$ & $\gamma$ & $R^{2}$ & DW & $\beta=1$ & $\gamma=1$ \\
\hline$\Delta i$ & $\begin{array}{l}0.2004 \\
(0.1641)\end{array}$ & $\begin{array}{l}-0.0531 \\
(0.0400)\end{array}$ & & & 0.0572 & 1.9656 & 0.0000 & \\
\hline$i$ & $\begin{array}{l}-3.8130^{*} \\
(2.0263)\end{array}$ & $\begin{array}{l}1.0315 * * * \\
(0.0840)\end{array}$ & & & 0.8341 & 1.0565 & 0.7103 & \\
\hline$\Delta i$ & $\begin{array}{l}-0.8593 \\
(2.2000)\end{array}$ & $\begin{array}{l}0.4179^{* * *} \\
(0.1749)\end{array}$ & $\begin{array}{c}-0.4133^{* *} \\
(0.1644)\end{array}$ & $\begin{array}{l}0.9711 * * * \\
(0.2065)\end{array}$ & 0.7772 & 2.3255 & 0.0025 & 0.8899 \\
\hline
\end{tabular}

*, **, *** represent 10,5 , and 1 percent level of significance, respectively. Unit root test by Augmented DickeyFuller (ADF) test suggests that both national saving and investment series are integrated of order one or I (1).

However, different findings were found when estimating the correlation between domestic investment and national saving. Both short-run and long-run coefficient are statistically significant at 5 percent level of significant. Furthermore, the unity test indicated that only short-run is statistically different from unity at 5 percent level of significant, while in the long-run, it does not reject null hypothesis at any level of significance.

Table 6. Net Foreign Investment (ca) and National Saving during Pre-crisis Period

\begin{tabular}{|c|c|c|c|c|c|c|c|c|}
\hline & $\alpha$ & $\beta$ & $\boldsymbol{\theta}$ & $\gamma$ & $R^{2}$ & DW & $\boldsymbol{\beta}=\mathbf{0}$ & $\gamma=\mathbf{0}$ \\
\hline$\Delta c a$ & $\begin{array}{l}-0.0491 \\
(0.4034)\end{array}$ & $\begin{array}{l}0.0435 \\
(0.0984)\end{array}$ & & & 0.0067 & 2.8697 & 0.6614 & \\
\hline$c a$ & $\begin{array}{l}4.8622^{* * *} \\
(2.0026)\end{array}$ & $\begin{array}{l}-0.0756 \\
(0.0830)\end{array}$ & & & 0.0269 & 1.0702 & 0.3700 & \\
\hline$\Delta c a$ & $\begin{array}{l}1.2750 \\
(2.4249)\end{array}$ & $\begin{array}{l}-0.0058 \\
(0.0978)\end{array}$ & $\begin{array}{l}-0.4976^{* * * *} \\
(0.1758)\end{array}$ & $\begin{array}{l}0.01898 \\
(0.1871)\end{array}$ & 0.2529 & 2.2161 & 0.9527 & 0.9199 \\
\hline
\end{tabular}

*, **, *** represent 10,5, and 1 percent level of significance, respectively. Unit root test by Augmented DickeyFuller (ADF) test suggests that both current account and national saving series are integrated of order one or I (1).

Table 6 presents the robustness check on saving-investment relationship. It indicates that only short-run coefficient $(\theta)$ is statistically significant, while long run coefficient of national saving is not statistically correlated with net foreign investment. Moreover, the unity test indicates that short-run coefficient is statistically not different from zero as it failed to reject null hypothesis at any level of significance. It is interesting that the net foreign investment does not show consistent findings with previous regression on domestic saving, national saving and domestic investment. In this robustness check, it appears that current account does not have one-to-one relationship with national saving as it fails to reject null hypothesis. 


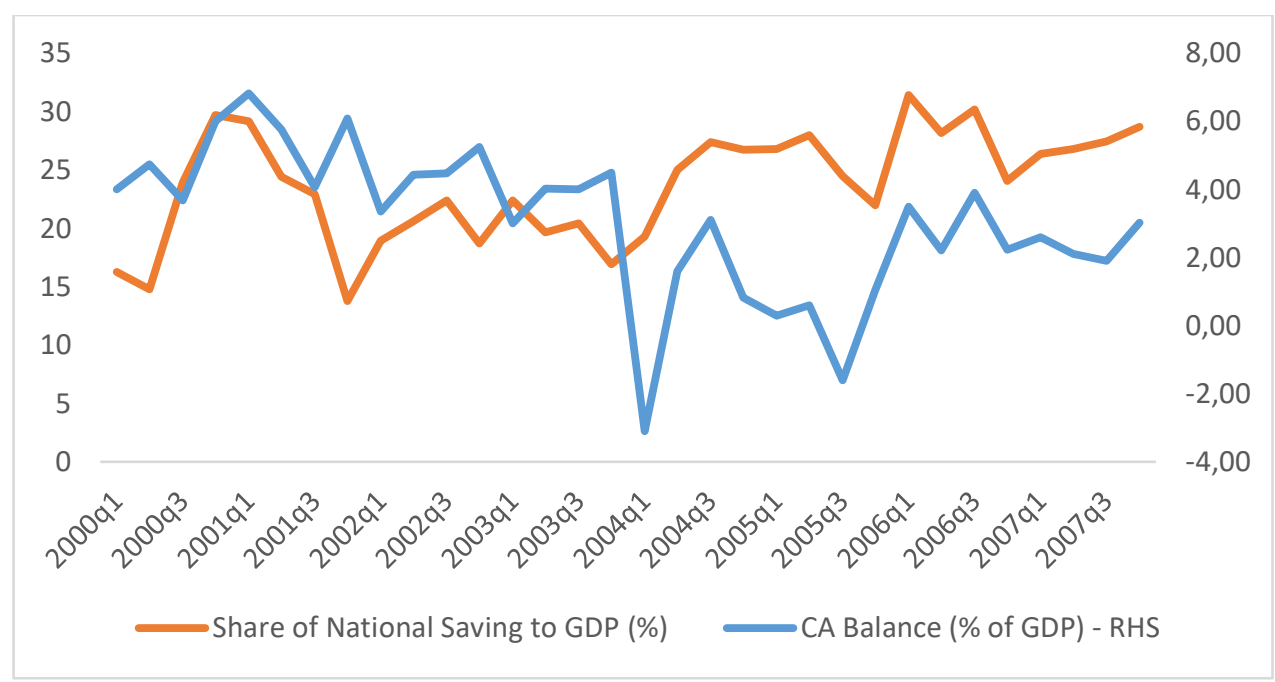

Figure 3. National Saving Rate and Current Account Balance

Source: Indonesia Central Bureau Statistic and Bank Indonesia

The graph shows that national saving rate and current account balance move together until 2004. Since 2004, current account started to experience deficit due to deficit on Indonesia's trade balance. Heavy policy on fuel subsidy which require massive import on oil and gas industry has deteriorated Indonesia's trade balance. As a result, the gap between national saving and current account balance became wider since 2004. Wider current account deficit indicate that investment is larger than saving, therefore the role of capital inflow is very substantial to meet investment requirement.

\section{$\underline{\text { Post-Global Financial Crisis }}$}

This section will discuss the estimation using OLS regression in level. Difference, and ECM for the period $2008-2018$ or post-crisis period.

Table 7. Domestic Investment and Domestic Saving during Post-crisis Period

\begin{tabular}{|c|c|c|c|c|c|c|c|c|}
\hline & $\alpha$ & $\beta$ & $\boldsymbol{\theta}$ & $\gamma$ & $R^{2}$ & DW & $\beta=1$ & $\gamma=1$ \\
\hline$\Delta i$ & $\begin{array}{l}0.1906 \\
(0.1217)\end{array}$ & $\begin{array}{l}-0.3285^{* * *} \\
(0.0306)\end{array}$ & & & 0.7378 & 2.2830 & 0.0000 & \\
\hline$i$ & $\begin{array}{l}16.46631 \text { **** } \\
(3.7040)\end{array}$ & $\begin{array}{l}0.4975^{* * * *} \\
(0.1103)\end{array}$ & & & 0.3262 & 0.7327 & 0.0000 & 16.46631 **** \\
\hline$\Delta i$ & $\begin{array}{l}5.8967 \\
(4.1013)\end{array}$ & $\begin{array}{l}0.1536 \\
(0.0982)\end{array}$ & $\begin{array}{l}-0.3880^{* * * *} \\
(0.1131)\end{array}$ & $\begin{array}{c}0.5455^{*} \\
(0.3034)\end{array}$ & 0.5588 & 2.5890 & 0.0000 & 0.1421 \\
\hline
\end{tabular}

*, **, *** represent 10,5 , and 1 percent level of significance, respectively. Unit root test by Augmented DickeyFuller (ADF) test suggests that both domestic saving and investment series are integrated of order one or I (1).

Table 7 shows the saving-investment relationship through domestic saving in the post-crisis period. The estimation for both short-run coefficient $(\theta)$ and long-run coefficient $(\gamma)$ are statistically significant at 1 percent level of significance. The unity test indicated only short-run has statistically different from unity, while the unity test for the long-run failures to reject null hypothesis. It indicates that in the short-run the movement of foreign capital is quite high, while in the long-run saving and investment would perfectly move together. 
Table 8. Domestic Investment and National Saving during Post-crisis Period

\begin{tabular}{|c|c|c|c|c|c|c|c|c|}
\hline & $\alpha$ & $\beta$ & $\theta$ & $\gamma$ & $R^{2}$ & DW & $\beta=1$ & $\gamma=1$ \\
\hline$\Delta i$ & $\begin{array}{l}0.1845 \\
(0.2093)\end{array}$ & $\begin{array}{l}-0.3260^{* * * *} \\
(0.0947)\end{array}$ & & & 0.2243 & 2.5516 & 0.0000 & \\
\hline$i$ & $\begin{array}{l}8.4615^{* *} \\
(4.3266)\end{array}$ & $\begin{array}{l}0.7750^{* * *} \\
(0.1357)\end{array}$ & & & 0.4370 & 0.3082 & 0.1049 & \\
\hline$\Delta i$ & $\begin{array}{l}0.7581 \\
(2.9138)\end{array}$ & $\begin{array}{l}0.6001^{* * *} \\
(0.1058)\end{array}$ & $\begin{array}{l}-0.2050^{* *} \\
(0.0836)\end{array}$ & $\begin{array}{l}0.9449 * * \\
(0.4355)\end{array}$ & 0.7962 & 2.0804 & 0.0005 & 0.9000 \\
\hline
\end{tabular}

However, similar finding in the first section when conducting overall period was found that estimation yields different result when we employed saving-investment relationship with regard of national saving. Both short-run and long-run coefficient are statistically significant at 5 percent level of significant. Furthermore, the unity test indicated that only short-run is statistically different from unity at 5 percent level of significant, while in the long-run, it does not reject null hypothesis at any level of significance.

Table 9. Net Foreign Investment (ca) and National Saving during Post-crisis Period

\begin{tabular}{|c|c|c|c|c|c|c|c|c|}
\hline & $\alpha$ & $\boldsymbol{\beta}$ & $\boldsymbol{\theta}$ & $\gamma$ & $R^{2}$ & DW & $\boldsymbol{\beta}=\mathbf{0}$ & $\gamma=\mathbf{0}$ \\
\hline$\Delta c a$ & $\begin{array}{l}-0.1422 \\
(0.1543)\end{array}$ & $\begin{array}{l}\text { O.2032*** } \\
(0.0698)\end{array}$ & & & 0.1713 & 2.2617 & 0.0058 & \\
\hline$c a$ & $\begin{array}{l}-8.4949^{* * *} \\
(4.3248)\end{array}$ & $\begin{array}{l}0.2260 \\
(0.1357)\end{array}$ & & & 0.0619 & 0.3118 & 0.1033 & \\
\hline$\Delta c a$ & $\begin{array}{l}-0.8001 \\
(2.9279)\end{array}$ & $\begin{array}{l}\text { O.1952** } \\
(0.0799)\end{array}$ & $\begin{array}{l}-0.2075^{* *} \\
(0.0840)\end{array}$ & $\begin{array}{c}0.06015 \\
(0.4316)\end{array}$ & 0.2884 & 2.0748 & 0.0193 & 0.8899 \\
\hline
\end{tabular}

Table 9 presents the robustness check on saving-investment relationship. It indicates that only short-run coefficient $(\theta)$ is statistically significant, while long run coefficient of national saving is not statistically correlated with net foreign investment. Moreover, the unity test indicates that only short-run is statistically different from zero as it rejects null hypothesis at 5 percent level of significance, while in the long-run, there is no evidence of zero correlation. This finding is consistent with the previous findings in saving-investment relationship that in the short-run, foreign capital inflow plays significant role for limited financing on domestic investment. While in the long-run, saving and investment have one-to-one relationship.

The results indicate that over the whole sample period, both domestic saving and national saving of short run coefficient, establish low significant coefficient which signifies high capital mobility. While in the long-run, the coefficient produced high significant coefficient, which does not necessarily indicate low capital movement. Jansen and Schulze (1996) claimed that in major cases, saving would move independently with investment in the steady state condition, while difference between domestic saving and domestic investment are only transitory or short-term phenomena. The result on the pre-crisis period suggested that domestic saving and domestic investment is not statistically correlated for both short-run and long-run as there is not enough evidence to reject null hypothesis. However, the relationship between domestic investment and national saving is 
statistically significant for both short-run and long-run. The unity test also shows consistent result with overall sample period which indicate low coefficient in short-run and high coefficient in long-run. The result of pre-crisis period indicates the similar findings with whole sample period.

Robustness check also confirmed that during whole sample period and post-crisis period, the net foreign investment would move together with national saving as the regression tend to reject the null hypothesis in short-run, while in the long run, the result does not consistent with the regression of domestic saving, national saving, and domestic investment. In the long-run, the coefficient also tends to reject null hypothesis, indicating net foreign investment has one to one correlation with national saving. Moreover, different findings were found in the pre-crisis period. A robustness coefficient is only statistically significant in short-run, while the long-run coefficient is not different from zero. For the parametric restriction test, both short-run and long-run do not statistically different from zero, which indicate that the capital mobility do not move perfectly with national saving. Therefore, it may be concluded that significant capital mobility was mostly generated during pre-crisis period. These findings are also consistent with descriptive data that showed the wider gap between national saving and current account balance since 2004 . Since 2004, the current account started to experience deficit which reflecting that investment is larger than saving and financial account was always in surplus to finance deficit in current account.

\section{Policy Implication}

Massive capital inflow to Indonesia after Asia financial crisis greatly impacted the stability of macroeconomic indicators. The value of rupiah against dollar appreciated on average by 1.3 percent during recovery period on 2002 to 2007 , depreciated by 1 percent after global financial crisis on 2008 to 2012, and depreciated by after taper tantrum crisis on 2013 to 2018. Domestic banks were vulnerable to the exposure of foreign exchange risk due to high amount of external financing, although it contributed to the acceleration of bank activities and credit growth. Beside affected on real exchange rate and banking industry, capital influx also contributed to the increase of asset price. Indonesian stock market price index showed upward trend, especially after 2004. However, since major contribution of investment occurred from short-term portfolio investment, it drew concern that external shocks would lead to the drop of asset price and reduction of foreign asset reserve.

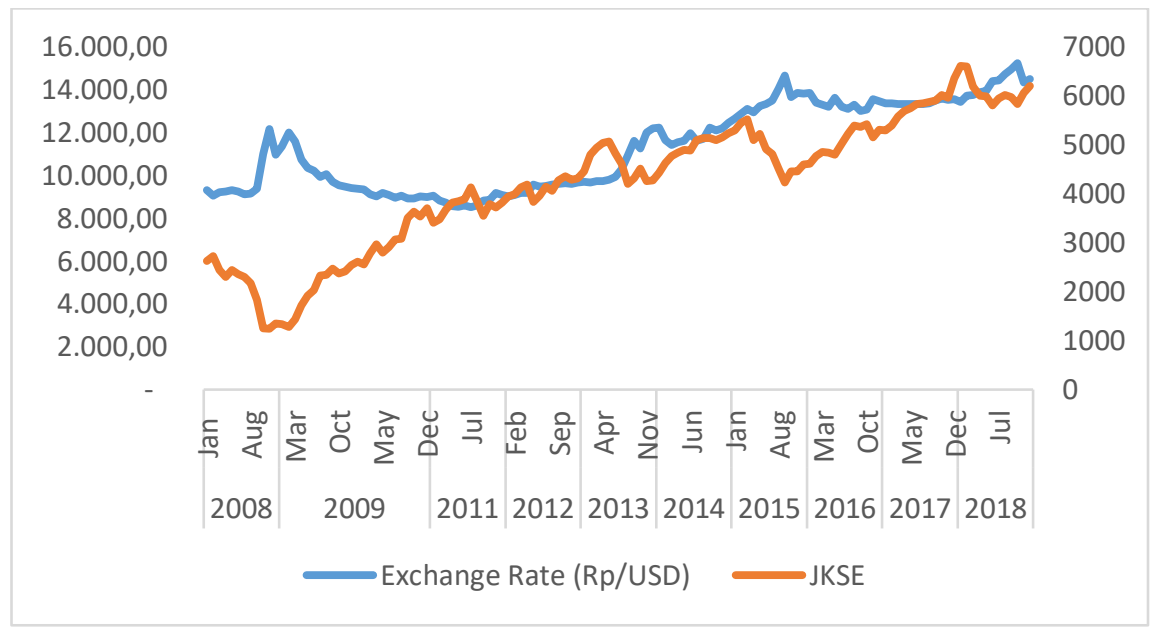

Figure 4. Movement of Exchange Rate and Indonesian Stock Market Index Source: CEIC 
The result of saving and investment relationship for the case of Indonesia in this study suggest that the capital mobility is relatively high in short-run, while in the longrun, saving has one to one relationship with domestic investment for the all periods observed. Low correlation between saving and investment in short-run may imply that the capital inflow to Indonesia is largely from the short-term form of capital inflow, such portfolio investment.

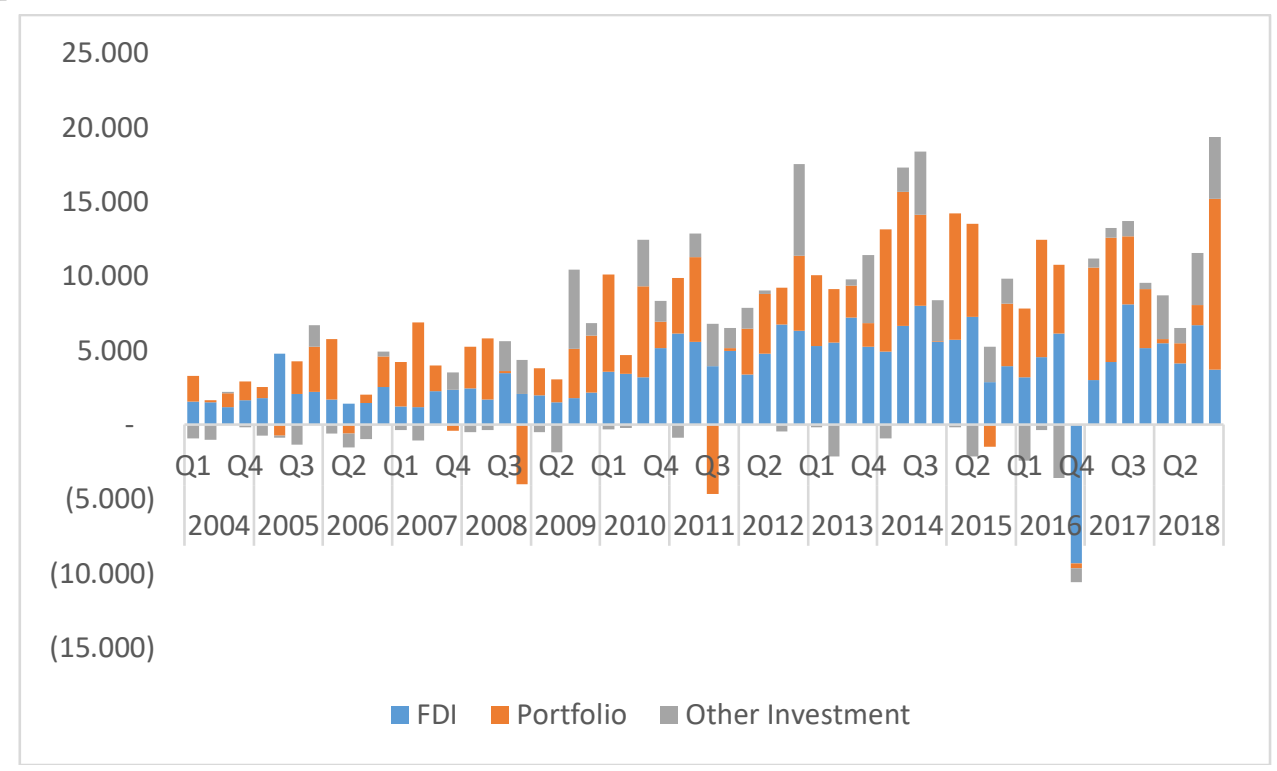

Figure 10. The composition of Gross Capital Flow (USD Million)

Source: Bank Indonesia

The graph above shows the composition of capital inflow in the form of foreign direct investment, portfolio, and other investment. From the graph above, although FDI has upward trend and continue to increase, the capital inflow is largely dominated by portfolio investment, particularly in the form of equity and debts issued by government and private sectors. Smith and Valderrama (2008) describe portfolio investments are very volatile as it would respond quickly to the global changes. Moreover, Tchorek (2017) examined that portfolio based on debt is more volatile to the changes of external factors such as interest rate differential between countries which takes form into yield of debt instrument.

In the part of policy response, Indonesia is not implementing restrictive capital control, however, from several episodes of crisis, the problem mostly caused by volatility in the capital market. Indonesia now focused on improving the macroeconomic fundamental and prudential regulation and supervision to gain investors confidence. Based on Bank Indonesia regulation, to limit speculative activities, Indonesian central bank restricts foreign exchange transaction. Additionally, Indonesian central bank also issued Bank Indonesia obligation to avoid high concentration in banking sector or financial market and develop prudent regulation for banking industry to compel the minimum capital requirements. Titiheruw and Atje (2008) argue that inflation targeting framework which implemented by Indonesian central bank since 2005 leaves three policy option in managing capital influx. The policies are including appreciation in exchange rate, reduction in interest rate to lower capital inflow, and capital control regulation. These policies, however, have unfavourable impact for external balance. For instance, appreciation in value of rupiah would likely reduce export competitiveness and reduction in interest rate also 
could potentially cause short-term jump inflation rate since credit growth in banking industry would likely to grow.

Moreover, learned from previous crises, Indonesian economy was very susceptible to the external changes. This dynamic was exaggerated when current account deficit and budget deficit were financed by short-term portfolio investment, particularly from debt. Basri (2017) proposed the implementation of reverse Tobin tax which would likely function as tax incentive. Unlike the original Tobin tax which aim to reduce speculative investment and country's currency by taxing investors who pull their money out of country in short period of time, reverse Tobin tax will work as tax incentive for foreign investors. This tax scheme performs as the taxation of short-term capital inflows to minimize the volatility in hot money and encourage investors to reinvest their earnings for long-term. It is expected that this policy would be accompanied by favourable monetary policy, fiscal policy, and economic stability, therefore it will not discourage the investors to put their money in Indonesia as the cost for investor is quite significant which limit the movement of investor money.

\section{Concluding Remarks}

This paper examines the role of capital inflow in Indonesia through saving and investment relationship. As strand literatures argue that capital inflow provide benefit in achieving high and sustained economic growth by accumulating capital and private saving, capital inflow provides funds to the recipient countries to invest and consume more than their capacity (Caselli \& Feyrer, 2007). Moreover, capital mobility may have different effect for developed and developing economies. Yan (2007) argue that in developed economies, foreign capital influx may be utilized to fund saving-investment gap, but it may cause current account imbalance in certain developing economies. The composition of capital inflow also plays significant role in determining the effect of capital inflow to economic growth and financial resilience. Baharumshah and Thanoon (2005) claim that foreign direct investment could draw the benefit of capital inflow to domestic economy as the result of their study suggest that implemented capital inflow policy countries performed better than countries which not have this policy. Therefore, the examination on the role of capital inflow may draw potential benefit for the policy maker in determining the optimal saving rate and domestic policy regarding the strategies to attract international capital inflow.

This study utilized Feldstein and Horioka framework (1980) that posit low correlation between domestic saving and investment should exposit high international capital movement. However, the result of Feldstein-Horioka study led to puzzle when they obtained one to one relationship between domestic saving and domestic investment and conclude that capital mobility is limited which contradicts the current perception that capital mobility is high across sample countries. Tesar (1991) found that the the implication of Feldstein-Horioka study on the degree of foreign capital movement is debatable. Summers (1988) examined that negative correlation between capital account and budget deficit indicated the endogeneity between government response and high foreign capital mobility. In other study, Feldstein and Bacchetta (1991) argue that this negative relationship caused by crowding out effect in the private sectors due to government borrowing.

Utilizing Feldstein-Horioka (1980) framework, this paper postulates the asymmetric relationship between domestic saving and investment in order to draw inferences regarding foreign capital movement. Although low or negative relationship between domestic saving and domestic investment imply substantial foreign capital movement, high correlation between these two variables does not necessarily imply low capital movement. An empirical evidence was performed to obtain the relationship between saving and investment. This study employs error correction model to obtain not only to meet reliable 
measurement on econometric specification, but also conclusive theoretical framework to prevent biased conclusion and purposeful interpretation. Moreover, error correction model could capture intertemporal general equilibrium models which substantial to gather cointegration correlation between domestic saving and domestic investment. Jansen (1996) argue that many literatures set up their model specification without considering the temporary phenomena or steady-state condition between domestic saving and domestic investment. He explained that in the major events of steady state condition, saving is always balanced with investment and the difference between these two variables (savinginvestment gap or current account imbalances) are transitory phenomena.

Employing error correction model for the case of Indonesian quarterly data from 2000 to 2018, this study found that over the whole sample period, both domestic saving and national saving of short run coefficient, establish low significant coefficient which signifies high capital mobility. While in the long-run, the coefficient produced high significant coefficient, which does not necessarily indicate low capital movement. The result on the pre-crisis period suggested that domestic saving and domestic investment is not statistically correlated for both short-run and long-run as there is not enough evidence to reject null hypothesis. However, the relationship between domestic investment and national saving is statistically significant for both short-run and long-run. The unity test also shows consistent result with overall sample period which indicate low coefficient in short-run and high coefficient in long-run. The result of pre-crisis period indicates the similar findings with whole sample period.

A robustness check that represents the relationship between net foreign investment (proxied by current account balance) was performed. It is expected that the estimation would reject the null hypothesis as defined by $\beta=0$ and $\gamma=0$. In the case of rejection of null hypothesis, this implies high degree of capital mobility. It confirmed that during whole sample period and post-crisis period, the net foreign investment would move together with national saving as the regression tend to reject the null hypothesis in short-run, while in the long run, the result does not consistent with the regression of domestic saving, national saving, and domestic investment as it indicated one to one correlation with national saving. Moreover, different findings were found in the pre-crisis period. A robustness coefficient is only statistically significant in short-run, while the long-run coefficient is not different from zero. For the parametric restriction test, both short-run and long-run do not statistically different from zero, which indicate that the capital mobility do not move perfectly with national saving. Therefore, it may be concluded that significant capital mobility was mostly generated during pre-crisis period.

Before global financial crisis broke out, Indonesia was in the recovery period from Asian financial crisis. The financial account recorded surplus since 2002 which dominated by portfolio investment. On the other side, current account balance started to be deficit since 2004 due to heavy regulation on fuel subsidy. Moreover, Global financial crisis in 2008 had little impact on Indonesian economy. Although, financial account indicated capital outflow in the forms of portfolio investment, FDI remained stable. The impact of global financial crisis has different measure from the Asian financial crisis since government implemented several policies reform such as the adoption of floating exchange rate and financial institution reform. Additionally, the right measure of monetary and fiscal policy response also plays important role in managing crisis. In the following years, Indonesia experienced taper tantrum as a result of U.S. policy to normalize its policy rate. Taper tantrum also mounted pressure for Indonesian current account and financial account. However, since Indonesia implemented switching expenditure policy to encounter the impact of taper tantrum, Indonesia successfully recovered from the disruptive effect within shorter period. As IMF (2015) reported that together with India, Indonesia only took 7 months to recover, reflected by increasing in equity price and relatively steady the 
yield of government bond in the first half of 2014 which in turn also increasing foreign asset reserve and stable value of rupiah against US dollar. Descriptive data also discovered the gap between pre-crisis period and post-crisis period. It shows that the wider gap between national saving and current account balance since 2004, reflecting that investment is larger than saving and the surplus in the financial account was used to finance deficit in current account.

This time patterns do not affect the correlation between saving and investment both for short-run and long-run coefficient. The Feldstein-Horioka puzzle holds for Indonesian case when capital mobility is high since 1970s and remained high for the sample period observed. The study confirms that the existence of high degree of capital mobility match with the value of domestic investment and domestic saving coefficient. Moreover, it also confirms the steady state equality that postulate the difference between domestic saving and domestic investment is transitory, while in the long run domestic saving and domestic investment will be equal. Since this study confirms the role of capital mobility for Indonesian economy, policy implications indicate that proper measurement in order to maintain capital inflow should be considered. The descriptive data suggests that portfolio investment in the form of debt were the biggest contributor of capital influx which more volatile than FDI. Moreover, Indonesian stock market were dominated by foreigners as they contributed more than 60 percent in the market (Falianty, 2017). Therefore, looking at these facts, Indonesian economy is susceptible to the shock of global economy.

Although capital inflow may cause disturbance to the Indonesian economy, it also could draw potential benefit. Therefore, the correct measurement in maintaining capital inflow should become the policy option. In order to accommodate these dynamic circumstances, an implementation of reverse Tobin tax was raised. Unlike the original Tobin tax which aim to reduce speculative investment and country's currency by taxing investors who pull their money out of country in short period of time, reverse Tobin tax will work as tax incentive for foreign investors. This tax scheme performs as the taxation of short-term capital inflows to minimize the volatility in hot money and encourage investors to reinvest their earnings for long-term.

This research has drawback as it is unable to capture the dynamic and cross-country parameter restriction. Moreover, to produce robust estimation which contribute to the ability of model to exploit the contemporaneous relationship between saving and investment of the error that indicate the common shocks, a panel approach is best suited econometric framework. Analysing through dynamic circumstances such as sudden stops, change in exchange rate mechanism, the role of reform should be taken into account to enrich the model specification through imposing different parameter restriction.

\section{Reference List}

Aizenman, J., \& Sushko, V. (2011). Capital flow types, external financing needs, and industrial growth: 99 countries, 1991-2007 (No. w17228). National Bureau of Economic Research.

Ahmed, S., \& Zlate, A. (2014). Capital flows to emerging market economies: a brave new world?. Journal of International Money and Finance, 48, 221-248.

Albuquerque, R., \& Loayza, N. Serveī n, L.(2005). World market integration through the lens of foreign direct investors. Journal of International Economics, 66, 267-295.

Bacchetta, P. (1992). Liberalization of capital movements and of the domestic financial system. ECONOMICA-LONDON-, 59, 465-465.

$\begin{array}{cccc}\text { Bank } & \text { Indonesia. } & \text { (2019). } & \text { External } \\ & \text { https://www.bi.go.id/en/statistik/seki/terkini/moneter/Contents/Default.aspx. }\end{array}$ 
Basri, M. C. (2016). The Fed's tapering talk: A short statement's long impact on Indonesia. Ash Center Occ-asional Papers. Ash Center, Harvard University.

Basri, M. C. (2017). India and Indonesia: Lessons learned from the 2013 taper tantrum. Bulletin of Indonesian Economic Studies, 53(2), 137-160.

Basri, M. C., \& Hill, H. (2011). Indonesian growth dynamics. Asian Economic Policy Review, 6(1), 90-107.

Basri, M. C., \& Rahardja, S. (2010). The Indonesian economy amidst the global crisis: good policy and good luck. ASEAN Economic Bulletin, 77-97.

Basri, M. C., \& Siregar, R. Y. (2009). Navigating policy responses at the national level in the midst of the global financial crisis: The experience of Indonesia. Asian Economic Papers, 8(3), 1-35.

Baxter, M., \& Crucini, M. J. (1993). Explaining saving--investment correlations. The American Economic Review, 416-436.

Bayoumi, T. (1990). Saving-investment correlations: immobile capital, government policy, or endogenous behavior?. Staff Papers, 37(2), 360-387.

Bayoumi, T. A., \& Rose, A. K. (1993). Domestic savings and intra-national capital flows. European Economic Review, 37(6), 1197-1202.

Bayoumi, T., Sarno, L., \& Taylor, M. P. (1999). European capital flows and regional risk. The Manchester School, 67(1), 21-38.

Bayoumi, T., \& Sterne, G. (1993). Regional trading blocs, mobile capital and exchange rate coordination.

Bekaert, G. (1995). Market integration and investment barriers in emerging equity markets. The World Bank Economic Review, 9(1), 75-107.

Bekaert, G., \& Harvey, C. R. (1998). Capital flows and the behavior of emerging market equity returns (No. w6669). National bureau of economic research.

Belke, A. H., Oeking, A., \& Setzer, R. (2014). Exports and Capacity Constraints: A smooth transition regression model for six euro-area countries. CEPS Working Documents, (395).

Blanchard, O. J., \& Fischer, S. (Eds.). (1989). NBER macroeconomics annual 1989 (Vol. 4). MIT Press.

Bohn, H., \& Tesar, L. L. (1996). US equity investment in foreign markets: portfolio rebalancing or return chasing?. The American Economic Review, 86(2), 77-81.

Bosworth, B. P., Collins, S. M., \& Reinhart, C. M. (1999). Capital flows to developing economies: implications for saving and investment. Brookings papers on economic activity, 1999(1), 143-180.

Broto, C., Diaz-Cassou, J., \& Erce-Dominguez, A. (2008). The sources of capital flows volatility: empirical evidence for emerging countries. Money Affairs, 21(1), 93-128.

Buiter, W. H. (1981). Time preference and international lending and borrowing in an overlapping-generations model. Journal of political economy, 89(4), 769-797.

Carlson, M. M. S., \& Hernández, M. L. (2002). Determinants and repercussions of the composition of capital inflows (No. 2-86). International Monetary Fund.

Caselli, F., \& Feyrer, J. (2007). The marginal product of capital. The Quarterly Journal of Economics, 122(2), 535-568.

Cavoli, T., \& Rajan, R. S. (2009). Exchange rate regimes and macroeconomic management in Asia (Vol. 1). Hong Kong University Press.

Chinn, M. D., \& Ito, H. (2008). A new measure of financial openness. Journal of comparative policy analysis, $10(3), 309-322$.

Chuhan, P., Claessens, S., \& Mamingi, N. (1993). Equity and bond flows to Asia and Latin America. Washington, DC: World Bank.

Chuhan, P., Perez-Quiros, G., \& Popper, H. (1996). International capital flows: do short-term investment and direct investment differ?. The World Bank. 
Combes, P. P., Duranton, G., \& Gobillon, L. (2010). The identification of agglomeration economies. Journal of economic geography, 11 (2), 253-266.

Coval, J. D., \& Moskowitz, T. J. (1999). Home bias at home: Local equity preference in domestic portfolios. The Journal of Finance, 54(6), 2045-2073.

De Haan, J., \& Siermann, C. L. (1994). Saving, investment, and capital mobility: A comment on Leachman. Open economies review, 5(1), 5-17.

Demirgüç-Kunt, A., \& Detragiache, E. (2001). Deposit insurance and moral hazard. In Federal Reserve Bank of Chicago Proceedings (No. 742).

Dornbusch, R., Goldfajn, I., Valdés, R. O., Edwards, S., \& Bruno, M. (1995). Currency crises and collapses. Brookings papers on economic activity, 1995(2), 219-293.

Dominguez, K. M., \& Frankel, J. A. (1993). Does foreign-exchange intervention matter? The portfolio effect. The American Economic Review, 83(5), 1356-1369.

Dooley, M., Frankel, J., \& Mathieson, D. J. (1987). International capital mobility: What do saving-investment correlations tell us?. Staff Papers, 34(3), 503-530.

Dooley, M., Helkie, W., Tryon, R., \& Underwood, J. (1986). An analysis of external debt positions of eight developing countries through 1990. Journal of Development Economics, 21(2), 283-318.

Dooley, M. P. (2000). A model of crises in emerging markets. The economic journal, $110(460), 256-272$.

Edwards, S. (2002). Does the current account matter?. In Preventing currency crises in emerging markets (pp. 21-76). University of Chicago Press.

Eichengreen, B., \& Gupta, P. (2014). Tapering talk: The impact of expectations of reduced Federal Reserve security purchases on emerging markets. The World Bank.

Engle, R. F., \& Granger, C. W. (1987). Co-integration and error correction: representation, estimation, and testing. Econometrica: journal of the Econometric Society, 251-276.

Falianty, T. (2018). Balance of Payment Dynamic in Indonesia and the Structure of Economy. Economics and Finance in Indonesia, 63(1), 53-80.

Feldstein, M. (1983). Inflation, income taxes, and the rate of interest: A theoretical analysis. In Inflation, Tax Rules, and Capital Formation (pp. 28-43). University of Chicago Press.

Feldstein, M., \& Bacchetta, P. (1991). National saving and international investment. In National saving and economic performance (pp. 201-226). University of Chicago press.

Feldstein, M. S., \& Horioka, C. Y. (1980). Domestic savings and international capital flows. Journal of Economics, 90(1):314-329.

Fernandez-Arias, E. (1996). The new wave of private capital inflows: push or pull?. Journal of development economics, 48(2), 389-418.

Fernandez-Arias, E., \& Hausmann, R. (2000). The new wave of capital inflows: Sea change or just another title?. Inter-American Development Bank Working Paper, 417.

Finn, M. G. (1990). On savings and investment dynamics in a small open economy. Journal of International Economics, 29(1-2), 1-21.

French, K. R., \& Poterba, J. M. (1991). Investor diversification and international equity markets (No. w3609). National Bureau of Economic Research.

Forbes, K. J., \& Warnock, F. E. (2012). Capital flow waves: Surges, stops, flight, and retrenchment. Journal of International Economics, 88(2), 235-251.

Frankel, J. A. (1991). 8 Quantifying International Capital Mobility in the 1980s. National Saving and kconomc Performance, 227.

Frankel, J. A. (1992). Measuring international capital mobility: a review. The American Economic Review, 82(2), 197-202.

Frankel, J. A., \& MacArthur, A. T. (1988). Political vs. currency premia in international real interest differentials: A study of forward rates for 24 countries. European Economic Review, 32(5), 1083-1114. 
Fratzscher, M. (2002). Financial market integration in Europe: on the effects of EMU on stock markets. International Journal of Finance \& Economics, 7(3), 165-193.

Fratzscher, M. (2012). Capital flows, push versus pull factors and the global financial crisis. Journal of International Economics, 88(2), 341-356.

Furceri, D., Guichard, S., \& Rusticelli, E. (2011). Episodes of large capital inflows and the likelihood of banking and currency crises and sudden stops.

Garrett, G. (2000). Shrinking states? Globalization and national autonomy. In The political economy of globalization (pp. 107-146). Palgrave, London.

Genberg, H., \& Swoboda, A. K. (1992). Saving, investment and the current account. The scandinavian journal of economics, 347-366.

Gertler, M., \& Rogoff, K. S. (1989). Developing country borrowing and domestic wealth.

Gertler, M., \& Rogoff, K. (1990). North-South lending and endogenous domestic capital market inefficiencies. Journal of monetary Economics, 26(2), 245-266.

Goldstein, M., Lane, T. D., Lizondo, J. S., Mathieson, D. J., Rojas-Suárez, L., \& FolkertsLandau, D. F. I. (1991). Determinants and systemic consequences of international capital flows (Vol. 77). International Monetary Fund.

Goldstein, M., \& Mussa, M. (1993). The integration of world capital markets (No. 93/95). International Monetary Fund.

Goeltom, M. S. (2008, December). Capital flows in Indonesia: challenges and policy responses. In Participants in the meeting (p. 265).

Gordon, R. H., \& Bovenberg, A. (1994). Why is capital so immobile internationally?: Possible explanations and implications for capital income taxation (No. w4796). National Bureau of Economic Research.

Grilli, V., \& Milesi-Ferretti, G. M. (1995). Economic effects and structural determinants of capital controls. Staff Papers, 42(3), 517-551.

Grubel, H. G. (1968). Internationally diversified portfolios: welfare gains and capital flows. The American Economic Review, 58(5), 1299-1314.

Gupta, D. D., \& Ratha, D. (2000). What Factors Appear to Drive Private Capital Flows to Developing Countries?: And how Does Official Lending Respond? (Vol. 2392). World Bank Publications.

Hadiwibowo, Y. (2010). Capital inflows and investment in developing countries: The case of Indonesia. International Journal of Applied Economics and Finance, 4(4), 220229.

Harberger, A. C. (1980). Vignettes on the world capital market. The American Economic Review, 7O(2), 331-337.

Hasanah, R. (2019). The Determinant of Capital Inflow to Indonesia: National and Global Determinant. A 3,000-words research proposal submitted for ECON7950 (Research Methods in Economics).

Hernández, M. L., Valdés, M. R. O., \& Melado, M. P. (2001). Determinants of Private Capital Flows in the 1970's and 1990's: Is there Evidence of Contagion? (No. 1-64). International Monetary Fund.

IMF, O. (2014). Strengthening the Contractual Framework to Address Collective Action Problems in Sovereign Debt Restructuring.

IMF (International Monetary Fund). 2014b. Global Financial Stability Report: Moving from Liquidity-to Growth-Driven Markets. Washington, DC: IMF.

IMF (International Monetary Fund). 2015. Indonesia: Staff Report for the 2014 Article IV Consultation. Washington, DC: IMF.

Ito, H., Jongwanich, J., \& Terada-Hagiwara, A. (2009). What makes developing Asia resilient in a financially globalized world?. Asian Development Bank Economics Working Paper Series, (181). 
Jansen, W. J., \& Schulze, G. G. (1996). "Theory-based Measurement of the SavingInvestment Correlation with an Application to Norway". Economic inquiry, 34(1), 116-132.

Johansen, S. (1988). Statistical analysis of cointegration vectors. Journal of economic dynamics and control, 12(2-3), 231-254.

Koepke, R. (2015). What drives capital flows to emerging markets. A Survey of the Empirical Literature. University Library of Munich, Germany.

Koutmos, G., \& Saidi, R. (2001). Positive feedback trading in emerging capital markets. Applied Financial Economics, $11(3)$, 291-297.

Kremers, J. J., Ericsson, N. R., \& Dolado, J. J. (1992). The power of cointegration tests. Oxford bulletin of economics and statistics, 54(3), 325-348.

Leachman, L. L. (1991). Saving, investment, and capital mobility among OECD countries. Open economies review, 2(2), 137-163.

Leiderman, L., \& Reinhart, C. M. (1993). Capital Inflows to Latin America: The Role of External Factors. IMF Staff Papers, 4O(1), 108-51.

Levy, D. (1995). Capital stock depreciation, tax rules, and composition of aggregate investment. Journal of Economic and Social Measurement, 21(1), 45-65.

Lucas, R. E. (1990). Why doesn't capital flow from rich to poor countries?. American Economic Review, 80(2), 92-96.

Matsuyama, K. (1987). Current account dynamics in a finite horizon model. Journal of International Economics, 23(3-4), 299-313.

Mcclure, J. H. (1994). The Feldstein-Horioka puzzle: The IS-LM model with optimal policy. Open economies review, 5(4), 371-382.

McKinnon, R. I. (1973). Money and Capital in Economic Development (Washington: Brookings Institute).

McKinnon, R. I. (1988). Monetary and exchange rate policies for international financial stability: a proposal. Journal of Economic Perspectives, 2(1), 83-103.

Mercado Jr, R. V., \& Park, C. Y. (2011). What drives different types of capital flows and their volatilities in developing Asia?. International Economic Journal, 25(4), 655-680.

Modjtahedi, B. (1988). Dynamics of real interest differentials: An empirical investigation. European Economic Review, 32(6), 1191-1211.

Mody, A., \& Murshid, A. P. (2005). Growing up with capital flows. Journal of international economics, 65(1), 249-266.

Murphy, R. G. (1984). Capital mobility and the relationship between saving and investment rates in OECD countries. Journal of international Money and Finance, 3(3), 327-342.

Neumann, R. M., Penl, R., \& Tanku, A. (2009). Volatility of capital flows and financial liberalization: Do specific flows respond differently?. International review of economics E finance, 18(3), 488-501.

Obstfeld, M. (1993). International capital mobility in the 1990s (No. w4534). National Bureau of Economic Research.

Perron, P. (1997). Further evidence on breaking trend functions in macroeconomic variables. Journal of econometrics, 80(2), 355-385.

Persson, T., \& Svensson, L. E. (1985). Current account dynamics and the terms of trade: Harberger-Laursen-Metzler two generations later. Journal of Political economy, 93(1), 43-65.

Razin, A., \& Sadka, E. (1995). Population economics. Mit Press.

Razin, A., \& Yuen, C. W. (1995). Utilitarian trade-off between population growth and income growth. Journal of Population Economics, 8(1), 81-87.

Rigobon, R. (2001). Does contagion exist?. In Risk Management: The State of the Art (pp. 163-166). Springer, Boston, MA. 
Sachs, J. (1983). The current account in the macroeconomic adjustment process. In LongRun Effects of Short-Run Stabilization Policy (pp. 15-27). Palgrave Macmillan, London.

Saghaian, S., \& Reed, M. (2015). Spillover effects of US Federal Reserve's recent quantitative easing On Canadian commodity prices. International Journal of Food and Agricultural Economics (IJFAEC), 3(1128-2016-92071), 43-11.

Shleifer, A., \& Vishny, R. (2011). Fire sales in finance and macroeconomics. Journal of Economic Perspectives, 25(1), 29-48.

Sinn, S. (1992). Saving-investment correlations and capital mobility: On the evidence from annual data. The Economic Journal, 102(414), 1162-1170.

Smith, K. A., \& Valderrama, D. (2008). Why do emerging economies import direct investment and export savings? A story of financial underdevelopment. working paper.

Soderstrom, H. Y. (1987). Sectoral Saving and Investment Patterns in 16 OECD countries, 1965-1982. Private Saving and Public Debt, Basil Blackwell, Oxford.

Soesastro, H., \& Basri, M. C. (1998). Survey of recent developments. Bulletin of Indonesian Economic Studies, 34(1), 3-54.

Stiglitz, J., Stiglitz, J. E. S., \& Greenwald, B. (2003). Towards a new paradigm in monetary economics. Cambridge university press.

Summers, L. H. (1988). Tax policy and international competitiveness. In International aspects of fiscal policies (pp. 349-386). University of Chicago Press.

Taylor, M. P., \& Sarno, L. (1997). Capital flows to developing countries: long-and shortterm determinants. The World Bank Economic Review, 11(3), 451-470.

Tchorek, G. (2017). Polish Exchange Rate Policy Dilemmas in ERM II. Studia Europejskie, 82(2), 43-67.

Tchorek, G., Brzozowski, M., \& Śliwiński, P. (2017). Determinants of capital flows to emerging and advanced economies between 1990 and 2011. Portuguese Economic Journal, 16(1), 17-48.

Tesar, L. L. (1991). Savings, investment and international capital flows. Journal of International economics, 31(1-2), 55-78.

Thanoon, M. A. M., \& Baharumshah, A. Z. (2005). What happened to savings during the financial crisis - a dynamic panel analysis of Asian-5 countries. Economic Change and Restructuring, 38(3-4), 257-275.

Titiheruw, I. S., Soesastro, H., \& Atje, R. (2009). Global Financial Crisis Discussion Series.

Tobing, L 2014, 'Current Account Deficit Sustainability: Financing Through Capital and Financial Account', Bank Indonesia Working Paper No. 72.

Tornell, A., \& Velasco, A. (1992). The tragedy of the commons and economic growth: why does capital flow from poor to rich countries?. Journal of Political Economy, 100(6), 1208-1231.

Van Zyl, H. (2002). The Importance of Financial Stability for Capital Flows to Emerging Economies Referring to the African Continent and South Africa. Journal of Applied Sciences, 2, 51-55.

Vikeren, B. (1994). Interest Rate Differentials, Exchange Rate Expectations and Capital Mobility: Norwegian Evidence. Norges Bank Skrftserie, 21.

Watkins, G. C., \& Streifel, S. (1997). Private capital flows to developing countries; the road to financial integration. The World Bank.

Williamson, J. (1993). Issues posed by portfolio investment in developing countries. World Bank Discussion Papers, 11-11.

Yan, H. D. (2007). Does capital mobility finance or cause a current account imbalance?. The Quarterly Review of Economics and Finance, 47(1), 1-25.

Ying, Y. H., \& Kim, Y. (2001). An empirical analysis on capital flows: the case of Korea and Mexico. Southern Economic Journal, 954-968. 
Zivot, E., \& Andrews, D. W. K. (2002). Further evidence on the great crash, the oil-price shock, and the unit-root hypothesis. Journal of business \& economic statistics, 20(1), 2544. 